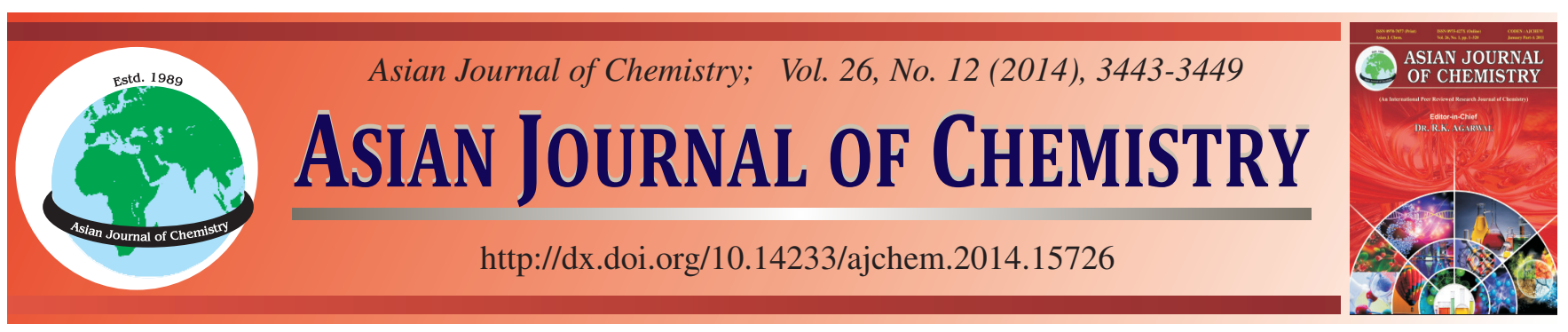

\title{
Heavy Metals Content in the Water Lakes of Barlinek-Gorzów Landscape Park (North-West Poland)
}

\author{
Piotr DANisZewsKi ${ }^{1, *}$ and RYSZARD KONIECZNY²
}

\begin{abstract}
${ }^{1}$ Department of Invertebrate Zoology and Limnology, Faculty of Biology, University of Szczecin, 13 Waska Street, 71-415 Szczecin, Poland
\end{abstract} ${ }^{2}$ Institute of Technological and Life Sciences Falenty, Branch Poznan, 67 Biskupiñska Street, 60-463 Poznan, Poland

*Corresponding author: E-mail: daniszewski73@gmail.com

Received: 3 May 2013;

Accepted: 16 July 2013;

Published online: 5 June 2014;

AJC-15268

\begin{abstract}
The present research work deals with the quantification of toxic heavy metals in the water samples collected from different lakes viz., Barlineckie lake, Glebokie lake, Lubiszewko lake and Przyleg lake of the Barlinek-Gorzów Landscape Park (North-West Poland). For this we took samples from Barlineckie lake, Glebokie lake, Lubiszewko lake and Przyleg lake for analysis of various heavy metals such as cadmium, chromium, copper, mercury, lead, zinc and nickel.
\end{abstract}

Keywords: Toxic Heavy Metals, Lake water, Barlinek-Gorzów Landscape Park (North-West Poland).

\section{INTRODUCTION}

Urbanization is the cause of many changes which are taking place in the environment, including those found in the catchment ${ }^{1-8}$. With this in mind, it is an important issue to properly protect water reservoirs and also take action to counter the adverse effects of human activities on the natural environment, including water bodies, ${ }^{2,5,9-17}$.

Heavy metal pollution is an ever increasing problem of our lakes ${ }^{1-4,9-11,18-28}$. These toxic heavy metals entering in aquatic environment are adsorbed onto particulate matter, although they can form free metal ions and soluble complexes that are available for uptake by biological organisms ${ }^{5,6,12-14,16,20-25,28-43}$. The increase in residue levels of heavy metal content in water, sediments and biota has resulted in decreased productivity and increase in exposure of humans to harmful substances ${ }^{15,16,28}$.

Many of these metals tend to remain in the ecosystem and eventually move from one compartment to the other within the food chain ${ }^{15,16,19-28,44-54}$. Food chain contamination by heavy metals has become a burning issue in recent years because of their potential accumulation in biosystems through contaminated water, soil, sediment and air ${ }^{15,16,24-28}$.

Hence in the present investigation, efforts are made to quantify the accumulation of toxic heavy metals in water in the lakes of the Barlinek-Gorzów Landscape Park (North-West Poland).

The study was carried out with an objective to generate the pollution load data from scientific study so as to gauge the extent of pollution due to toxic heavy metals in the lake water.

\section{EXPERIMENTAL}

The Barlinek-Gorzów Landscape Park was established in October 1991. The Barlinek-Gorzów Landscape Park includes more than 55000 ha of forests, lakes, fields, meadows and is characterized by a great diversity of habitats and abundant life forms ${ }^{55}$.

To protect the most valuable plant communities and animal habitats, five nature reserves were created within the boundaries of the Park:

(1) Skalisty Jar Libberta includes Libbert's Gorge and the surrounding moraine hills and glacial erratics. It is the only site featuring lime stones and boulders in Western Pomerania and is surrounded by oak and beech forests ${ }^{55}$.

(2) Debina forest conservation complex known as the Central European wet-ground forest, featuring stately oaks and beeches with some lime, hornbeam and old pine trees. In its clean environment, as many as 50 species of arboreal lichen have been preserved ${ }^{55}$.

(3) Markowe Blota - marshland, with its typical vegetation such as the Sphagnopsida, wild rosemary, ordinary cranberry, cottongrass. The site is visited quite often by whitetailed eagles ${ }^{55}$.

(4) The water reserve of the river Przylezek. It includes a section of the river, the slopes of the riverbank and the surrounding beech stand with some tree specimens that are more than 100 years old. Seen as the watercourse resembles mountain streams, with its pure and cold water, it provides appropriate conditions for Salmonidae to live and $\operatorname{spawn}^{55}$. 
(5) The forest reserve 'Wilanów' aims to protects the natural mixed forest with vintage beech, oak and pine trees. Thanks to the varied topography, diverse rare types of forests have been preserved here ${ }^{55}$.

Nature conservation in the park also includes natural monuments, animate and inanimate: 41 trees, 1 boulder, 3 rocks and the natural spring 'Bozy Dar' ${ }^{5}$.

The study covered seven lakes within the boundaries of the Barlinek-Gorzów Landscape Park: Barlineckie lake, Glebokie lake, Lubiszewko lake, Przyleg lake.

Barlineckie lake: The area of the lake covers 260 hectares, the depth reaches $18.0 \mathrm{~m}$, max length is $3.8 \mathrm{~km}$ lake is located in the North. Barlineckie parts of the Park, at a height of $57 \mathrm{~m}$ above sea level and is part of the Mysliborskie ${ }^{55}$.

Glebokie lake: The surface of the lake Glebokie in Barlinek is: 4.65 ha, maximum depth $-8 \mathrm{~m}^{55}$.

Lubiszewko lake: The surface of this lake covers 52 ha, depth, width is $11.8 \mathrm{~m}$ dating back to $520 \mathrm{~m}$, length up to $2100 \mathrm{~m}$. Lake is located at a height of $63.3 \mathrm{~m}$ above sea level ${ }^{55}$.

Przyleg lake: The surface of the lake is 43.2 ha, depth to $5.9 \mathrm{~m}, 650.0 \mathrm{~m}$ width, the length of $1,100 \mathrm{~m}^{55}$.

Research was carried out in the years 2008-2012, in the period from April to October.

The water samples collected from different sampling stations were filtered using $(0.45 \mu \mathrm{m}$ pore size $)$ filter paper to remove suspended particles. Filtrates were preserved in polythene bottles. In order to prevent the precipitation of metals 2 $\mathrm{mL}$ nitric acid was added to the filtrate ${ }^{28}$.

The samples were concentrated to tenfold on a water bath and subjected to nitric acid digestion ${ }^{31,49}$. About $400 \mathrm{~mL}$ of the sample was transformed into clean glass separating funnel in which $10 \mathrm{~mL}$ of $2 \%$ ammonium pyrrolidine dithiocarbamate, $4 \mathrm{~mL}$ of $0.5 \mathrm{M} \mathrm{HCl}$ and $10 \mathrm{~mL}$ of methyl isobutyl ketone (MIBK) are added ${ }^{28,56}$. The solution in separating funnel was shaken vigorously for $2 \mathrm{~min}$ and was left undisturbed for the phases to separate.

The methyl isobutyl ketone extract containing the desired metals was then diluted to give final volumes depending on the suspected level of the metals ${ }^{15,16,28,30}$. The sample solution was then aspirated into air acetylene flame in an atomic absorption spectrophotometer.

The analysis for the majority of the trace metals like cadmium, chromium, copper, mercury, nickel, lead and zinc was done by atomic absorption spectrophotometer.

\section{RESULTS AND DISCUSSION}

The experimental data on toxic heavy metals in water samples collected along the in lakes of the Barlinek-Gorzów Landscape Park from the month of 2008-2012 (April to October) is presented in Tables 1-4.

In the present investigation in water in the Barlineckie lake, it was observed that the maximum concentration of $\mathrm{Cd}$ was $0.42 \mathrm{ppm}$ and the minimum was $0.19 \mathrm{ppm}$ (Table-1). While the annual average concentration was calculated as $0.35 \mathrm{ppm}$ in 2008 of the year, $0.29 \mathrm{ppm}$ in 2009 of the year, $0.29 \mathrm{ppm}$ in 2010 of the year, $0.27 \mathrm{ppm}$ in 2011 of the year and $0.30 \mathrm{ppm}$ in 2012 of the year.

In the present investigation in water in the Glebokie lake, it was observed that the maximum concentration of $\mathrm{Cd}$ was

\begin{tabular}{|c|c|c|c|c|c|c|c|}
\hline \multicolumn{8}{|c|}{$\begin{array}{c}\text { TABLE-1 } \\
\text { HEAVY METALS CONTENT IN WATER SAMPLES } \\
\text { COLLECTED FROM BARLINECKIE LAKE } \\
\text { AT DIFFERENT PERIODS }\end{array}$} \\
\hline $\begin{array}{c}\text { Heavy } \\
\text { metals (ppm) }\end{array}$ & $\mathrm{Cd}$ & $\mathrm{Cr}$ & $\mathrm{Cu}$ & $\mathrm{Hg}$ & $\mathrm{Ni}$ & $\mathrm{Pb}$ & $\mathrm{Zn}$ \\
\hline \multicolumn{8}{|c|}{ April to October 2008} \\
\hline Apr. 2008 & 0.36 & 0.71 & 0.05 & 0.04 & 2.04 & 0.08 & 2.71 \\
\hline May 2008 & 0.33 & 0.69 & 0.04 & 0.03 & 2.52 & 0.06 & 3.41 \\
\hline June 2008 & 0.39 & 0.78 & 0.06 & 0.03 & 2.37 & 0.07 & 3.27 \\
\hline July 2008 & 0.31 & 0.82 & 0.07 & 0.04 & 1.83 & 0.07 & 2.82 \\
\hline Aug. 2008 & 0.42 & 0.78 & 0.06 & 0.02 & 2.53 & 0.09 & 3.64 \\
\hline Sept. 2008 & 0.37 & 0.64 & 0.07 & 0.03 & 2.18 & 0.07 & 3.71 \\
\hline Oct. 2008 & 0.29 & 0.80 & 0.06 & 0.04 & 2.07 & 0.07 & 3.21 \\
\hline Average & 0.35 & 0.74 & 0.06 & 0.03 & 2.22 & 0.07 & 3.25 \\
\hline \multicolumn{8}{|c|}{ April to October 2009} \\
\hline Apr. 2009 & 0.19 & 0.79 & 0.05 & 0.04 & 2.39 & 0.04 & 2.41 \\
\hline May 2009 & 0.25 & 0.52 & 0.07 & 0.03 & 1.93 & 0.07 & 2.37 \\
\hline June 2009 & 0.32 & 0.75 & 0.06 & 0.05 & 2.04 & 0.05 & 3.64 \\
\hline July 2009 & 0.30 & 0.23 & 0.07 & 0.04 & 2.26 & 0.06 & 3.29 \\
\hline Aug. 2009 & 0.37 & 0.39 & 0.08 & 0.03 & 2.58 & 0.07 & 3.32 \\
\hline Sept. 2009 & 0.32 & 0.47 & 0.05 & 0.04 & 2.52 & 0.04 & 3.07 \\
\hline Oct. 2009 & 0.31 & 0.69 & 0.08 & 0.05 & 2.32 & 0.05 & 2.82 \\
\hline Average & 0.29 & 0.55 & 0.06 & 0.04 & 2.29 & 0.05 & 2.99 \\
\hline \multicolumn{8}{|c|}{ April to October 2010} \\
\hline Apr. 2010 & 0.22 & 0.78 & 0.05 & 0.04 & 2.12 & 0.04 & 2.57 \\
\hline May 2010 & 0.25 & 0.35 & 0.07 & 0.03 & 1.94 & 0.06 & 3.26 \\
\hline June 2010 & 0.29 & 0.79 & 0.06 & 0.04 & 2.36 & 0.05 & 3.61 \\
\hline July 2010 & 0.32 & 0.63 & 0.05 & 0.05 & 2.58 & 0.06 & 2.84 \\
\hline Aug. 2010 & 0.35 & 0.42 & 0.05 & 0.05 & 2.92 & 0.05 & 3.42 \\
\hline Sept. 2010 & 0.31 & 0.93 & 0.07 & 0.04 & 2.63 & 0.07 & 3.59 \\
\hline Oct. 2010 & 0.28 & 0.67 & 0.06 & 0.05 & 2.85 & 0.07 & 3.62 \\
\hline Average & 0.29 & 0.65 & 0.06 & 0.04 & 2.48 & 0.06 & 3.27 \\
\hline \multicolumn{8}{|c|}{ April to October 2011} \\
\hline Apr. 2011 & 0.23 & 0.83 & 0.05 & 0.07 & 1.95 & 0.07 & 2.63 \\
\hline May 2011 & 0.27 & 0.79 & 0.07 & 0.04 & 1.83 & 0.05 & 2.79 \\
\hline June 2011 & 0.22 & 0.85 & 0.05 & 0.05 & 2.49 & 0.07 & 3.21 \\
\hline July 2011 & 0.32 & 0.51 & 0.06 & 0.06 & 2.07 & 0.06 & 2.84 \\
\hline Aug. 2011 & 0.26 & 0.58 & 0.07 & 0.05 & 2.41 & 0.05 & 2.78 \\
\hline Sept. 2011 & 0.29 & 0.69 & 0.08 & 0.05 & 1.73 & 0.07 & 3.14 \\
\hline Oct. 2011 & 0.32 & 0.95 & 0.05 & 0.03 & 2.24 & 0.05 & 3.40 \\
\hline Average & 0.27 & 0.74 & 0.06 & 0.05 & 2.10 & 0.06 & 2.97 \\
\hline \multicolumn{8}{|c|}{ April to October 2012} \\
\hline Apr. 2012 & 0.34 & 0.56 & 0.06 & 0.06 & 1.92 & 0.04 & 2.07 \\
\hline May 2012 & 0.27 & 0.95 & 0.04 & 0.03 & 2.62 & 0.07 & 2.75 \\
\hline June 2012 & 0.25 & 0.62 & 0.07 & 0.05 & 1.93 & 0.06 & 3.78 \\
\hline July 2012 & 0.31 & 0.83 & 0.04 & 0.05 & 2.49 & 0.06 & 2.47 \\
\hline Aug. 2012 & 0.26 & 0.39 & 0.05 & 0.07 & 2.37 & 0.04 & 2.38 \\
\hline Sept. 2012 & 0.33 & 0.72 & 0.06 & 0.06 & 1.82 & 0.07 & 2.72 \\
\hline Oct. 2012 & 0.36 & 0.97 & 0.07 & 0.05 & 2.16 & 0.07 & 2.59 \\
\hline Average & 0.30 & 0.72 & 0.05 & 0.05 & 2.19 & 0.06 & 2.68 \\
\hline
\end{tabular}

$0.34 \mathrm{ppm}$ and the minimum was $0.19 \mathrm{ppm}$ (Table-2). While the annual average concentration was calculated as $0.28 \mathrm{ppm}$ in 2008 of the year, $0.27 \mathrm{ppm}$ in 2009 of the year, $0.26 \mathrm{ppm}$ in 2010 of the year, $0.26 \mathrm{ppm}$ in 2011 of the year and $0.25 \mathrm{ppm}$ in 2012 of the year.

In the present investigation in water of the Lubiszewko lake, it was observed that the maximum concentration of $\mathrm{Cd}$ was $0.39 \mathrm{ppm}$ and the minimum was $0.19 \mathrm{ppm}$ (Table-3). While the annual average concentration was calculated as $0.29 \mathrm{ppm}$ in 2008 of the year, $0.26 \mathrm{ppm}$ in 2009 of the year, $0.30 \mathrm{ppm}$ in 2010 of the year, $0.27 \mathrm{ppm}$ in 2011 of the year and $0.25 \mathrm{ppm}$ in 2012 of the year. 

COLLECTED FROM GLEBOKIE LAKE AT DIFFERENT PERIODS

\begin{tabular}{|c|c|c|c|c|c|c|c|}
\hline $\begin{array}{c}\text { Heavy } \\
\text { metals (ppm) }\end{array}$ & $\mathrm{Cd}$ & $\mathrm{Cr}$ & $\mathrm{Cu}$ & $\mathrm{Hg}$ & $\mathrm{Ni}$ & $\mathrm{Pb}$ & $\mathrm{Zn}$ \\
\hline \multicolumn{8}{|c|}{ April to October 2008} \\
\hline Apr. 2008 & 0.27 & 0.19 & 0.03 & 0.04 & 2.03 & 0.03 & 2.04 \\
\hline May 2008 & 0.23 & 0.27 & 0.04 & 0.03 & 1.37 & 0.05 & 2.41 \\
\hline June 2008 & 0.31 & 0.24 & 0.04 & 0.04 & 1.21 & 0.03 & 3.27 \\
\hline July 2008 & 0.28 & 0.12 & 0.06 & 0.03 & 1.64 & 0.04 & 2.82 \\
\hline Aug. 2008 & 0.37 & 0.26 & 0.04 & 0.04 & 1.93 & 0.05 & 3.64 \\
\hline Sept. 2008 & 0.29 & 0.15 & 0.06 & 0.05 & 2.04 & 0.04 & 3.78 \\
\hline Oct. 2008 & 0.24 & 0.15 & 0.05 & 0.05 & 1.82 & 0.03 & 2.61 \\
\hline Average & 0.28 & 0.20 & 0.06 & 0.04 & 1.72 & 0.04 & 2.94 \\
\hline \multicolumn{8}{|c|}{ April to October 2009} \\
\hline Apr. 2009 & 0.28 & 0.42 & 0.06 & 0.04 & 1.41 & 0.03 & 1.83 \\
\hline May 2009 & 0.24 & 0.25 & 0.04 & 0.06 & 1.63 & 0.06 & 2.73 \\
\hline June 2009 & 0.29 & 0.32 & 0.06 & 0.06 & 1.34 & 0.07 & 3.15 \\
\hline July 2009 & 0.25 & 0.31 & 0.03 & 0.03 & 1.75 & 0.06 & 2.30 \\
\hline Aug. 2009 & 0.26 & 0.13 & 0.05 & 0.04 & 2.05 & 0.05 & 2.69 \\
\hline Sept. 2009 & 0.32 & 0.17 & 0.05 & 0.04 & 1.63 & 0.07 & 2.82 \\
\hline Oct. 2009 & 0.27 & 0.13 & 0.06 & 0.06 & 1.34 & 0.06 & 1.86 \\
\hline Average & 0.27 & 0.25 & 0.05 & 0.05 & 1.59 & 0.06 & 2.48 \\
\hline \multicolumn{8}{|c|}{ April to October 2010} \\
\hline Apr. 2010 & 0.19 & 0.24 & 0.06 & 0.03 & 1.38 & 0.05 & 1.85 \\
\hline May 2010 & 0.24 & 0.22 & 0.08 & 0.05 & 1.63 & 0.07 & 1.94 \\
\hline June 2010 & 0.23 & 0.20 & 0.05 & 0.06 & 2.06 & 0.03 & 2.36 \\
\hline July 2010 & 0.28 & 0.17 & 0.07 & 0.04 & 2.15 & 0.06 & 2.17 \\
\hline Aug. 2010 & 0.31 & 0.22 & 0.05 & 0.05 & 2.38 & 0.05 & 2.28 \\
\hline Sept. 2010 & 0.32 & 0.18 & 0.07 & 0.03 & 1.75 & 0.04 & 1.82 \\
\hline Oct. 2010 & 0.28 & 0.19 & 0.06 & 0.05 & 2.17 & 0.06 & 1.96 \\
\hline Average & 0.26 & 0.20 & 0.06 & 0.04 & 1.93 & 0.05 & 2.05 \\
\hline \multicolumn{8}{|c|}{ April to October 2011} \\
\hline Apr. 2011 & 0.23 & 0.33 & 0.04 & 0.04 & 1.82 & 0.04 & 1.87 \\
\hline May 2011 & 0.26 & 0.26 & 0.07 & 0.07 & 1.89 & 0.05 & 1.40 \\
\hline June 2011 & 0.24 & 0.21 & 0.07 & 0.05 & 1.38 & 0.07 & 2.48 \\
\hline July 2011 & 0.25 & 0.19 & 0.08 & 0.04 & 2.29 & 0.05 & 2.53 \\
\hline Aug. 2011 & 0.27 & 0.23 & 0.06 & 0.06 & 2.31 & 0.06 & 2.64 \\
\hline Sept. 2011 & 0.31 & 0.18 & 0.07 & 0.06 & 1.72 & 0.07 & 2.96 \\
\hline Oct. 2011 & 0.28 & 0.16 & 0.08 & 0.04 & 2.38 & 0.05 & 2.93 \\
\hline Average & 0.26 & 0.22 & $\mathbf{0 . 0 7}$ & 0.05 & 1.97 & 0.05 & 2.40 \\
\hline \multicolumn{8}{|c|}{ April to October 2012} \\
\hline Apr. 2012 & 0.21 & 0.16 & 0.06 & 0.04 & 1.62 & 0.04 & 2.72 \\
\hline May 2012 & 0.24 & 0.21 & 0.03 & 0.06 & 1.39 & 0.06 & 2.68 \\
\hline June 2012 & 0.19 & 0.18 & 0.06 & 0.03 & 1.71 & 0.04 & 2.74 \\
\hline July 2012 & 0.28 & 0.17 & 0.04 & 0.07 & 1.87 & 0.05 & 2.63 \\
\hline Aug. 2012 & 0.23 & 0.19 & 0.06 & 0.05 & 2.36 & 0.06 & 2.29 \\
\hline Sept. 2012 & 0.34 & 0.16 & 0.06 & 0.04 & 1.73 & 0.04 & 2.61 \\
\hline Oct. 2012 & 0.29 & 0.18 & 0.07 & 0.04 & 2.32 & 0.05 & 2.75 \\
\hline Average & 0.25 & 0.18 & 0.05 & 0.05 & 1.86 & 0.05 & 2.63 \\
\hline
\end{tabular}

In present study, the water of the Przyleg lake, it was observed that the maximum concentration of Cd was $0.47 \mathrm{ppm}$ and the minimum was $0.19 \mathrm{ppm}$ (Table-4). While the annual average concentration was calculated as $0.34 \mathrm{ppm}$ in 2008 of the year, $0.25 \mathrm{ppm}$ in 2009 of the year, $0.24 \mathrm{ppm}$ in 2010 of the year, $0.24 \mathrm{ppm}$ in 2011 of the year and $0.21 \mathrm{ppm}$ in 2012 of the year.

The values obtained were found to be below the permissible limit of $2.0 \mathrm{ppm}$ set for inland surface water ${ }^{28}$. There are a few recorded instances cadmium poisoning in human beings following consumption of contaminated fishes ${ }^{15,16,28}$. Cadmium it is less toxic to plants than $\mathrm{Cu}$, similar in toxicity
TABLE-3

HEAVY METALS CONTENT IN WATER SAMPLES COLLECTED FROM LUBISZEWKO LAKE AT DIFFEENT PERIODS

\begin{tabular}{|c|c|c|c|c|c|c|c|}
\hline $\begin{array}{c}\text { Heavy } \\
\text { metals (ppm) }\end{array}$ & $\mathrm{Cd}$ & $\mathrm{Cr}$ & $\mathrm{Cu}$ & $\mathrm{Hg}$ & $\mathrm{Ni}$ & $\mathrm{Pb}$ & $\mathrm{Zn}$ \\
\hline \multicolumn{8}{|c|}{ April to October 2008} \\
\hline Apr. 2008 & 0.28 & 0.26 & 0.04 & 0.05 & 2.31 & 0.04 & 2.47 \\
\hline May 2008 & 0.25 & 0.24 & 0.06 & 0.04 & 2.06 & 0.07 & 2.93 \\
\hline June 2008 & 0.33 & 0.27 & 0.08 & 0.04 & 2.39 & 0.05 & 2.75 \\
\hline July 2008 & 0.30 & 0.19 & 0.04 & 0.06 & 1.67 & 0.05 & 2.05 \\
\hline Aug. 2008 & 0.28 & 0.24 & 0.06 & 0.05 & 2.27 & 0.06 & 3.27 \\
\hline Sept. 2008 & 0.32 & 0.17 & 0.04 & 0.06 & 2.58 & 0.04 & 2.74 \\
\hline Oct. 2008 & 0.28 & 0.25 & 0.05 & 0.06 & 2.73 & 0.05 & 3.63 \\
\hline Average & 0.29 & 0.23 & 0.05 & 0.05 & 2.29 & 0.05 & 2.83 \\
\hline \multicolumn{8}{|c|}{ April to October 2009} \\
\hline Apr. 2009 & 0.25 & 0.16 & 0.06 & 0.05 & 1.48 & 0.03 & 2.27 \\
\hline May 2009 & 0.23 & 0.19 & 0.07 & 0.07 & 2.52 & 0.04 & 2.38 \\
\hline June 2009 & 0.27 & 0.22 & 0.03 & 0.04 & 2.49 & 0.06 & 3.17 \\
\hline July 2009 & 0.19 & 0.18 & 0.06 & 0.06 & 2.17 & 0.08 & 2.84 \\
\hline Aug. 2009 & 0.26 & 0.24 & 0.04 & 0.07 & 2.46 & 0.06 & 2.67 \\
\hline Sept. 2009 & 0.34 & 0.18 & 0.04 & 0.04 & 1.73 & 0.05 & 2.71 \\
\hline Oct. 2009 & 0.29 & 0.16 & 0.07 & 0.05 & 2.35 & 0.04 & 2.59 \\
\hline Average & 0.26 & 0.19 & 0.05 & 0.05 & 2.17 & 0.05 & 2.66 \\
\hline \multicolumn{8}{|c|}{ April to October 2010} \\
\hline Apr. 2010 & 0.39 & 0.14 & 0.06 & 0.03 & 1.40 & 0.06 & 2.29 \\
\hline May 2010 & 0.27 & 0.18 & 0.04 & 0.06 & 2.62 & 0.03 & 2.37 \\
\hline June 2010 & 0.25 & 0.23 & 0.08 & 0.05 & 1.48 & 0.05 & 1.79 \\
\hline July 2010 & 0.32 & 0.17 & 0.05 & 0.08 & 1.69 & 0.04 & 2.37 \\
\hline Aug. 2010 & 0.27 & 0.18 & 0.07 & 0.07 & 2.24 & 0.06 & 2.94 \\
\hline Sept. 2010 & 0.33 & 0.15 & 0.04 & 0.06 & 1.72 & 0.05 & 2.51 \\
\hline Oct. 2010 & 0.27 & 0.17 & 0.06 & 0.07 & 2.18 & 0.03 & 2.48 \\
\hline Average & 0.30 & 0.17 & 0.06 & 0.06 & 1.90 & 0.04 & 2.39 \\
\hline \multicolumn{8}{|c|}{ April to October 2011} \\
\hline Apr. 2011 & 0.21 & 0.26 & 0.05 & 0.03 & 1.48 & 0.05 & 2.85 \\
\hline May 2011 & 0.28 & 0.23 & 0.04 & 0.07 & 1.73 & 0.07 & 2.62 \\
\hline June 2011 & 0.26 & 0.17 & 0.06 & 0.05 & 1.86 & 0.07 & 2.38 \\
\hline July 2011 & 0.24 & 0.19 & 0.07 & 0.05 & 2.29 & 0.04 & 2.49 \\
\hline Aug. 2011 & 0.26 & 0.23 & 0.05 & 0.07 & 2.41 & 0.05 & 2.85 \\
\hline Sept. 2011 & 0.35 & 0.19 & 0.04 & 0.06 & 1.68 & 0.07 & 2.73 \\
\hline Oct. 2011 & 0.28 & 0.24 & 0.08 & 0.04 & 2.17 & 0.05 & 2.97 \\
\hline Average & 0.27 & 0.21 & 0.05 & 0.04 & 1.94 & 0.06 & 2.70 \\
\hline \multicolumn{8}{|c|}{ April to October 2012} \\
\hline Apr. 2012 & 0.22 & 0.13 & 0.05 & 0.04 & 1.48 & 0.04 & 2.14 \\
\hline May 2012 & 0.26 & 0.15 & 0.04 & 0.07 & 1.93 & 0.07 & 2.72 \\
\hline June 2012 & 0.19 & 0.23 & 0.07 & 0.05 & 1.58 & 0.03 & 2.78 \\
\hline July 2012 & 0.24 & 0.17 & 0.06 & 0.06 & 2.02 & 0.06 & 2.49 \\
\hline Aug. 2012 & 0.25 & 0.22 & 0.06 & 0.04 & 2.37 & 0.05 & 2.52 \\
\hline Sept. 2012 & 0.32 & 0.18 & 0.07 & 0.08 & 1.95 & 0.05 & 2.58 \\
\hline Oct. 2012 & 0.27 & 0.17 & 0.08 & 0.04 & 2.19 & 0.07 & 2.83 \\
\hline Average & 0.25 & 0.18 & 0.06 & 0.05 & 1.93 & 0.05 & 2.58 \\
\hline
\end{tabular}

to $\mathrm{Pb}$ and $\mathrm{Cr}^{15,16,28}$. It is equally toxic to invertebrates and fishes ${ }^{15,16,28,48}$. In aquatic systems, cadmium is most readily absorbed by organisms directly from the water in its free ionic form $\mathrm{Cd}(\mathrm{II})^{2,15,16,28}$.

The acute toxicity of cadmium to aquatic organisms is variable, even between closely related species and is related to the free ionic concentration of the metal ${ }^{2,15,16,28}$. Cadmium interacts with the calcium metabolism of animals ${ }^{2,15,16,28}$. In fish it causes lack of calcium (hypocalcaemia), probably by inhibiting calcium uptake from the water ${ }^{5,19,20,60}$.

In the present investigation in water in the Barlineckie lake, it was observed that the maximum concentration of $\mathrm{Cr}$ 


\begin{tabular}{|c|c|c|c|c|c|c|c|}
\hline \multicolumn{8}{|c|}{$\begin{array}{c}\text { TABLE-4 } \\
\text { HEAVY METALS CONTENT IN WATER SAMPLES } \\
\text { COLLECTED FROM PRZYLEG LAKE } \\
\text { AT DIFFERENT PERIODS }\end{array}$} \\
\hline $\begin{array}{c}\text { Heavy } \\
\text { metals (ppm) }\end{array}$ & $\mathrm{Cd}$ & $\mathrm{Cr}$ & $\mathrm{Cu}$ & $\mathrm{Hg}$ & $\mathrm{Ni}$ & $\mathrm{Pb}$ & $\mathrm{Zn}$ \\
\hline \multicolumn{8}{|c|}{ April to October 2008} \\
\hline Apr. 2008 & 0.28 & 0.13 & 0.04 & 0.06 & 1.58 & 0.03 & 2.71 \\
\hline May 2008 & 0.36 & 0.18 & 0.07 & 0.04 & 2.42 & 0.06 & 3.18 \\
\hline June 2008 & 0.33 & 0.24 & 0.05 & 0.05 & 1.62 & 0.08 & 3.36 \\
\hline July 2008 & 0.26 & 0.18 & 0.04 & 0.07 & 1.63 & 0.06 & 2.72 \\
\hline Aug. 2008 & 0.35 & 0.22 & 0.07 & 0.04 & 2.35 & 0.07 & 3.06 \\
\hline Sept. 2008 & 0.47 & 0.18 & 0.06 & 0.06 & 2.73 & 0.05 & 3.15 \\
\hline Oct. 2008 & 0.36 & 0.17 & 0.08 & 0.04 & 2.58 & 0.08 & 2.81 \\
\hline Average & 0.34 & 0.18 & 0.06 & 0.05 & 2.13 & 0.06 & 2.99 \\
\hline \multicolumn{8}{|c|}{ April to October 2009} \\
\hline Apr. 2009 & 0.22 & 0.21 & 0.06 & 0.04 & 1.74 & 0.06 & 2.71 \\
\hline May 2009 & 0.27 & 0.23 & 0.03 & 0.07 & 1.69 & 0.03 & 2.59 \\
\hline June 2009 & 0.18 & 0.27 & 0.07 & 0.04 & 1.82 & 0.04 & 2.27 \\
\hline July 2009 & 0.24 & 0.18 & 0.07 & 0.06 & 2.19 & 0.05 & 2.54 \\
\hline Aug. 2009 & 0.25 & 0.22 & 0.04 & 0.07 & 2.47 & 0.05 & 2.18 \\
\hline Sept. 2009 & 0.31 & 0.19 & 0.06 & 0.04 & 1.83 & 0.03 & 2.62 \\
\hline Oct. 2009 & 0.28 & 0.24 & 0.08 & 0.03 & 2.16 & 0.07 & 2.49 \\
\hline Average & 0.25 & 0.22 & 0.06 & 0.05 & 1.98 & 0.05 & 2.49 \\
\hline \multicolumn{8}{|c|}{ April to October 2010} \\
\hline Apr. 2010 & 0.25 & 0.17 & 0.04 & 0.08 & 1.37 & 0.06 & 2.19 \\
\hline May 2010 & 0.21 & 0.21 & 0.06 & 0.05 & 1.64 & 0.03 & 2.44 \\
\hline June 2010 & 0.23 & 0.25 & 0.07 & 0.06 & 1.73 & 0.07 & 3.76 \\
\hline July 2010 & 0.19 & 0.18 & 0.04 & 0.07 & 2.06 & 0.03 & 2.47 \\
\hline Aug. 2010 & 0.25 & 0.22 & 0.09 & 0.08 & 2.28 & 0.06 & 2.64 \\
\hline Sept. 2010 & 0.32 & 0.17 & 0.05 & 0.04 & 1.52 & 0.05 & 2.73 \\
\hline Oct. 2010 & 0.27 & 0.18 & 0.08 & 0.06 & 2.26 & 0.07 & 2.29 \\
\hline Average & 0.24 & 0.20 & 0.07 & 0.06 & 1.84 & 0.05 & 2.64 \\
\hline \multicolumn{8}{|c|}{ April to October 2011} \\
\hline Apr. 2011 & 0.17 & 0.23 & 0.04 & 0.07 & 1.41 & 0.06 & 2.17 \\
\hline May 2011 & 0.23 & 0.21 & 0.07 & 0.04 & 1.59 & 0.03 & 2.81 \\
\hline June 2011 & 0.26 & 0.18 & 0.03 & 0.06 & 1.74 & 0.06 & 2.46 \\
\hline July 2011 & 0.29 & 0.24 & 0.05 & 0.04 & 2.07 & 0.05 & 1.83 \\
\hline Aug. 2011 & 0.24 & 0.22 & 0.06 & 0.03 & 2.36 & 0.07 & 1.69 \\
\hline Sept. 2011 & 0.29 & 0.16 & 0.04 & 0.06 & 1.85 & 0.06 & 2.37 \\
\hline Oct. 2011 & 0.21 & 0.24 & 0.05 & 0.07 & 2.74 & 0.08 & 2.42 \\
\hline Average & 0.24 & 0.21 & 0.05 & 0.05 & 1.96 & 0.06 & 2.25 \\
\hline \multicolumn{8}{|c|}{ April to October 2012} \\
\hline Apr. 2012 & 0.28 & 0.14 & 0.05 & 0.07 & 1.48 & 0.04 & 2.27 \\
\hline May 2012 & 0.21 & 0.22 & 0.07 & 0.03 & 1.74 & 0.06 & 2.18 \\
\hline June 2012 & 0.19 & 0.21 & 0.05 & 0.06 & 1.62 & 0.04 & 2.63 \\
\hline July 2012 & 0.17 & 0.18 & 0.07 & 0.05 & 2.04 & 0.06 & 2.39 \\
\hline Aug. 2012 & 0.23 & 0.23 & 0.06 & 0.08 & 2.62 & 0.07 & 2.37 \\
\hline Sept. 2012 & 0.18 & 0.18 & 0.07 & 0.06 & 1.85 & 0.03 & 2.52 \\
\hline Oct. 2012 & 0.22 & 0.19 & 0.04 & 0.05 & 2.32 & 0.06 & 2.91 \\
\hline Average & 0.21 & 0.19 & 0.06 & 0.06 & 1.95 & 0.06 & 2.47 \\
\hline
\end{tabular}

was $0.97 \mathrm{ppm}$ and the minimum was $0.23 \mathrm{ppm}$ (Table- 1 ). While the annual average concentration was calculated as $0,74 \mathrm{ppm}$ in 2008 of the year, $0.55 \mathrm{ppm}$ in 2009 of the year, $0.65 \mathrm{ppm}$ in 2010 of the year, $0.74 \mathrm{ppm}$ in 2011 of the year and $0.72 \mathrm{ppm}$ in 2012 of the year.

In the present investigation in water of the Glebokie lake, it was observed that the maximum concentration of $\mathrm{Cr}$ was $0.42 \mathrm{ppm}$ and the minimum was $0.12 \mathrm{ppm}$ (Table-2). While the annual average concentration was calculated as $0,20 \mathrm{ppm}$ in 2008 of the year, $0.25 \mathrm{ppm}$ in 2009 of the year, $0.20 \mathrm{ppm}$ in 2010 of the year, $0.22 \mathrm{ppm}$ in 2011 of the year and $0.18 \mathrm{ppm}$ in 2012 of the year.
In the present investigation in water of the Lubiszewko lake, it was observed that the maximum concentration of $\mathrm{Cr}$ was $0.24 \mathrm{ppm}$ and the minimum was $0.13 \mathrm{ppm}$ (Table-3). While the annual average concentration was calculated as $0.23 \mathrm{ppm}$ in 2008 of the year, $0.19 \mathrm{ppm}$ in 2009 of the year, $0.17 \mathrm{ppm}$ in 2010 of the year, $0.21 \mathrm{ppm}$ in 2011 of the year and $0.18 \mathrm{ppm}$ in 2012 of the year.

In the present investigation in water of the Przyleg lake, it was observed that the maximum concentration of $\mathrm{Cr}$ was 0.27 ppm and the minimum was 0.13 ppm (Table-4). While the annual average concentration was calculated as $0,18 \mathrm{ppm}$ in 2008 of the year, $0.22 \mathrm{ppm}$ in 2009 of the year, $0.20 \mathrm{ppm}$ in 2010 of the year, $0.21 \mathrm{ppm}$ in 2011 of the year and $0.19 \mathrm{ppm}$ in 2012 of the year.

Which was very much above the permissible limit of 0.1 ppm set for inland surface water ${ }^{28}$. For invertebrates and fishes, its toxicity is not much acute ${ }^{28}$. Chromium is generally more toxic at higher temperatures and its compounds are known to cause cancer in humans ${ }^{15,16,28,57}$. The toxic effect of chromium on plants indicate that the roots remain small and the leaves narrow, exhibit reddish brown discoloration with small necrotic blotches $^{8}$. Symptoms of chromium phytotoxicity include inhibition of seed germination or of early seedling development, reduction of root growth, leaf chlorosis and depressed biomass ${ }^{15,16,28,57}$.

From the results it appears that the $\mathrm{Cu}$ contents in water of the Barlineckie lake was minimum of $0.04 \mathrm{ppm}$ and maximum of $0.08 \mathrm{ppm}$ (Table-1). The observed annual average concentration of copper in the water was $0.06 \mathrm{ppm}$ in 2008 of the year, $0.06 \mathrm{ppm}$ in 2009 of the year, $0.06 \mathrm{ppm}$ in 2010 of the year, $0.06 \mathrm{ppm}$ in 2011 of the year and $0.05 \mathrm{ppm}$ in 2012 of the year.

From the results it appears that the $\mathrm{Cu}$ contents in water of the Glebokie lake was minimum of $0.03 \mathrm{ppm}$ and maximum of $0.08 \mathrm{ppm}$ (Table-2). The observed annual average concentration of copper in the water was $0.06 \mathrm{ppm}$ in 2008 of the year, $0.05 \mathrm{ppm}$ in 2009 of the year, $0.06 \mathrm{ppm}$ in 2010 of the year, $0.07 \mathrm{ppm}$ in 2011 of the year and $0.05 \mathrm{ppm}$ in 2012 of the year.

From the results it appears that the $\mathrm{Cu}$ content in water of the Lubiszewko lake was minimum of $0.03 \mathrm{ppm}$ and maximum of 0.08 ppm (Table- 3 ). The observed annual average concentration of copper in the water was $0.05 \mathrm{ppm}$ in 2008 of the year, $0.05 \mathrm{ppm}$ in 2009 of the year, $0.06 \mathrm{ppm}$ in 2010 of the year, $0.05 \mathrm{ppm}$ in 2011 of the year and $0.06 \mathrm{ppm}$ in 2012 of the year.

From the results it appears that the $\mathrm{Cu}$ content in water of the Przyleg lake was minimum of $0.03 \mathrm{ppm}$ and maximum of $0.09 \mathrm{ppm}$ (Table-4). The observed annual average concentration of Copper in the water was $0.06 \mathrm{ppm}$ in 2008 of the year, 0.06 ppm in 2009 of the year, 0.07 ppm in 2010 of the year, 0.05 ppm in 2011 of the year and 0.06 ppm in 2012 of the year.

Which was below the permissible limit of $3.0 \mathrm{ppm}$ set for inland surface water ${ }^{28}$. It is important here to note that copper is highly toxic to most fishes, invertebrates and aquatic plants than any other heavy metal except mercury ${ }^{28}$. It reduces growth and rate of reproduction in plants and animals ${ }^{28}$. The chronic level of $\mathrm{Cu}$ is $0.02-0.2 \mathrm{ppm}^{28,58}$. Aquatic plants absorb three 
times more copper than plants on dry lands ${ }^{28}$. Excessive copper contents can cause damage to roots, by attacking the cell membrane and destroying the normal membrane structure, inhibited root growth and formation of numerous short, brownish secondary roots ${ }^{28,58}$. Copper is highly toxic in aquatic environments and has effects in fish, invertebrates and amphibians, with all three groups equally sensitive to chronic toxicity $^{15,16,28,36}$. Copper also causes reduced sperm and egg production in many species of fish ${ }^{15,16,20-23,28,59}$.

In the present investigation in water in the Barlineckie lake, it was observed that the maximum concentration of $\mathrm{Hg}$ was $0.07 \mathrm{ppm}$ and the minimum was $0.02 \mathrm{ppm}$ (Table-1). While the annual average concentration was calculated as $0.03 \mathrm{ppm}$ in 2008 of the year, $0.04 \mathrm{ppm}$ in 2009 of the year, $0.04 \mathrm{ppm}$ in 2010 of the year, $0.05 \mathrm{ppm}$ in 2011 of the year and $0.05 \mathrm{ppm}$ in 2012 of the year.

In the present investigation in water of the Glebokie lake, it was observed that the maximum concentration of $\mathrm{Hg}$ was $0.07 \mathrm{ppm}$ and the minimum was $0.03 \mathrm{ppm}$ (Table-2). While the annual average concentration was calculated as $0.04 \mathrm{ppm}$ in 2008 of the year, $0.05 \mathrm{ppm}$ in 2009 of the year, $0.04 \mathrm{ppm}$ in 2010 of the year, $0.05 \mathrm{ppm}$ in 2011 of the year and $0.05 \mathrm{ppm}$ in 2012 of the year.

In the present investigation in water in the Lubiszewko lake, it was observed that the maximum concentration of $\mathrm{Hg}$ was $0.08 \mathrm{ppm}$ and the minimum was $0.03 \mathrm{ppm}$ (Table-3). While the annual average concentration was calculated as $0.05 \mathrm{ppm}$ in 2008 of the year, $0.05 \mathrm{ppm}$ in 2009 of the year, $0.06 \mathrm{ppm}$ in 2010 of the year, $0.04 \mathrm{ppm}$ in 2011 of the year and $0.05 \mathrm{ppm}$ in 2012 of the year.

In the present study, the water of the Przyleg lake, it was observed that the maximum concentration of $\mathrm{Hg}$ was $0.08 \mathrm{ppm}$ and the minimum was $0.03 \mathrm{ppm}$ (Table-4). While the annual average concentration was calculated as $0.05 \mathrm{ppm}$ in 2008 of the year, $0.05 \mathrm{ppm}$ in 2009 of the year, $0.06 \mathrm{ppm}$ in 2010 of the year, $0.05 \mathrm{ppm}$ in 2011 of the year and $0.06 \mathrm{ppm}$ in 2012 of the year.

Which was very much above the maximum limit of 0.01 ppm set for inland surface water ${ }^{28}$. Mercury is generated naturally in the environment from the degassing of the earth's crust from volcanic emissions ${ }^{28}$.

The organic form is readily absorbed in the gastrointestinal tract (90-100 \%), lesser but still significant amounts of inorganic mercury are absorbed in the gastrointestinal tract (7-15 $\%)^{28}$. Previous study have reported that Mercury in dissolved form enter the fish through the gills ${ }^{13,15,16,28}$. Further studies have indicated that inorganic Mercury get adsorbed to the suspended particulate matter and settles down $n^{15,16,28,40}$. Further gets methylated and ultimately enter the food chain, resulting in bioaccumulation ${ }^{28}$.

The monthly concentration of $\mathrm{Ni}$ in the water of Barlinek lake samples was found to be in the range of 1.73-2.92 ppm (Table-1). The annual average concentration of nickel in the water samples was observed to be $2.22 \mathrm{ppm}$ in 2008 of the year, $2.29 \mathrm{ppm}$ in 2009 of the year, $2.48 \mathrm{ppm}$ in 2010 of the year, $2.10 \mathrm{ppm}$ in 2011 of the year and $2.19 \mathrm{ppm}$ in 2012 of the year.

The monthly concentration of $\mathrm{Ni}$ in the water of Glebokie lake samples was found to be in the range of 1.21-2.38 ppm
(Table-2). The annual average concentration of nickel in the water samples was observed to be $1.72 \mathrm{ppm}$ in 2008 of the year, $1.59 \mathrm{ppm}$ in 2009 of the year, $1.93 \mathrm{ppm}$ in 2010 of the year, $1.97 \mathrm{ppm}$ in 2011 of the year and $1.86 \mathrm{ppm}$ in 2012 of the year.

The monthly concentration of $\mathrm{Ni}$ in the water of Lubiszewko lake samples was found to be in the range of 1.40$2.62 \mathrm{ppm}$ (Table-3). The annual average concentration of nickel in the water samples was observed to be $1.72 \mathrm{ppm}$ in 2008 of the year, $1.59 \mathrm{ppm}$ in 2009 of the year, $1.93 \mathrm{ppm}$ in 2010 of the year, $1.97 \mathrm{ppm}$ in 2011 of the year and $1.86 \mathrm{ppm}$ in 2012 of the year.

The monthly concentration of Ni in the water in Przyleg lake samples was found to be in the range of 1.41-2.74 ppm (Table-4). The annual average concentration of nickel in the water samples was observed to be $2.13 \mathrm{ppm}$ in 2008 of the year, $1.98 \mathrm{ppm}$ in 2009 of the year, $1.84 \mathrm{ppm}$ in 2010 of the year, $1.96 \mathrm{ppm}$ in 2011 of the year and $1.95 \mathrm{ppm}$ in 2012 of the year.

Which is close to the limit of $3 \mathrm{ppm}$ set for inland surface water ${ }^{28}$. Short-term exposure to Nickel on human being is not known to cause any health problems, but long-term exposure can cause decreased body weight, heart, liver damage and skin irritation $^{15,16,28,58}$.

In the present investigation in water of the Barlineckie lake, it was observed that the maximum concentration of $\mathrm{Pb}$ was $0.09 \mathrm{ppm}$ and the minimum was $0.04 \mathrm{ppm}$ (Table-1). The annual average concentration of $\mathrm{Pb}$ in the water samples was observed to be $0.07 \mathrm{ppm}$ in 2008 of the year, $0.05 \mathrm{ppm}$ in 2009 of the year, $0.06 \mathrm{ppm}$ in 2010 of the year, $0.06 \mathrm{ppm}$ in 2011 of the year and $0.06 \mathrm{ppm}$ in 2012 of the year.

In the present investigation in water of the Glebokie lake, it was observed that the maximum concentration of $\mathrm{Pb}$ was $0.07 \mathrm{ppm}$ and the minimum was $0.03 \mathrm{ppm}$ (Table-2). The annual average concentration of $\mathrm{Pb}$ in the water samples was observed to be $0.04 \mathrm{ppm}$ in 2008 of the year, $0.06 \mathrm{ppm}$ in 2009 of the year, $0.05 \mathrm{ppm}$ in 2010 of the year, $0.05 \mathrm{ppm}$ in 2011 of the year and 0.05 ppm in 2012 of the year.

In the present study in water of the Lubiszewko lake, it was observed that the maximum concentration of $\mathrm{Pb}$ was 0.07 ppm and the minimum was 0.03 ppm (Table-3). The annual average concentration of $\mathrm{Pb}$ in the water samples was observed to be $0.05 \mathrm{ppm}$ in 2008 of the year, $0.05 \mathrm{ppm}$ in 2009 of the year, $0.04 \mathrm{ppm}$ in 2010 of the year, $0.06 \mathrm{ppm}$ in 2011 of the year and $0.05 \mathrm{ppm}$ in 2012 of the year.

In the present investigation in water of the Przyleg lake, it was observed that the maximum concentration of $\mathrm{Pb}$ was 0.08 ppm and the minimum was 0.03 ppm (Table-4). The annual average concentration of $\mathrm{Pb}$ in the water samples was observed to be $0.06 \mathrm{ppm}$ in 2008 of the year, $0.05 \mathrm{ppm}$ in 2009 of the year, $0.05 \mathrm{ppm}$ in 2010 of the year, $0.06 \mathrm{ppm}$ in 2011 of the year and $0.06 \mathrm{ppm}$ in 2012 of the year.

Which is above the permissible limit of $0.1 \mathrm{ppm}$ set for inland surface water ${ }^{28}$. Acute toxicity generally appears in aquatic plants at concentration of $0.1-5.0 \mathrm{ppm}^{28,58}$. In plants, it initially results in enhanced growth, but from a concentration of 5 ppm onwards, this is counteracted by severe growth retardation, discoloration and morphological abnormalities ${ }^{28}$. 
There is an adverse influence on photosynthesis, respiration and other metabolic processes ${ }^{28}$. Acute toxicity of Lead in invertebrates is reported at concentration of $0.1-10 \mathrm{ppm}^{15,16,28,58}$. Higher levels pose eventual threat to fisheries resources ${ }^{28}$. A number of studies have investigated effects of prolonged Lead exposure on freshwater fish ${ }^{28}$. These studies report a wide range of effects induced by chronic exposure to elevated Lead concentrations, oocyte growth, including effects on pituitary function, gonadosomatic index $\mathrm{x}^{15,16,28,54}$.

In the present study in water of the Barlineckie lake, the monthly concentration of zinc was in the range of $2.27 \mathrm{ppm}$ to $3.70 \mathrm{ppm}$ (Table-1). The results of the present investigation indicate that the annual average concentration of $\mathrm{Zn}$ in water samples was 3.25 ppm in 2008 of the year, 2.99 ppm in 2009 of the year, $3.27 \mathrm{ppm}$ in 2010 of the year, $2.97 \mathrm{ppm}$ in 2011 of the year and 2.68 ppm in 2012 of the year.

In the present study in water of the Glebokie lake, the monthly concentration of zinc was in the range of $1.40 \mathrm{ppm}$ to $3.78 \mathrm{ppm}$ (Table-2). The results of the present investigation indicate that the annual average concentration of $\mathrm{Zn}$ in water samples was 2.94 ppm in 2008 of the year, 2.48 ppm in 2009 of the year, $2.05 \mathrm{ppm}$ in 2010 of the year, $2.40 \mathrm{ppm}$ in 2011 of the year and $2.63 \mathrm{ppm}$ in 2012 of the year.

In the present study in water of the Lubiszewko lake, the monthly concentration of zinc was in the range of $1.79 \mathrm{ppm}$ to $3.63 \mathrm{ppm}$ (Table-3). The results of the present investigation indicate that the annual average concentration of $\mathrm{Zn}$ in water samples was 2.83 ppm in 2008 of the year, 2.66 ppm in 2009 of the year, $3.39 \mathrm{ppm}$ in 2010 of the year, $2.70 \mathrm{ppm}$ in 2011 of the year and $2.58 \mathrm{ppm}$ in 2012 of the year.

In the present study in water of the Przyleg lake, the monthly concentration of zinc was in the range of $1.69 \mathrm{ppm}$ to $3.76 \mathrm{ppm}$ (Table-4). The results of the present investigation indicate that the annual average concentration of $\mathrm{Zn}$ in water samples was 2.99 ppm in 2008 of the year, 2.49 ppm in 2009 of the year, $2.64 \mathrm{ppm}$ in 2010 of the year, $2.25 \mathrm{ppm}$ in 2011 of the year and $2.47 \mathrm{ppm}$ in 2012 of the year.

Which is above the permissible limit of $5.0 \mathrm{ppm}$ set for inland surface water ${ }^{28}$. Zinc may result in ne crosis, chlorosis and inhibited growth of plants ${ }^{28,58}$. Previous studies have reported toxic effect of Zinc on some aquatic organisms such as fish ${ }^{15,16,18,28}$. Although there is low toxicity effect of $\mathrm{Zn}$ in man, however, the prolonged consumption of large doses has been reported to show some health complications such as fatigue, dizziness and neutropenia ${ }^{15,16,28,36}$.

\section{Conclusions}

In the present investigation of the water of the Barlineckie lake, it was observed that the maximum concentration of $\mathrm{Cd}$ was $0.42 \mathrm{ppm}$ and the minimum was $0.19 \mathrm{ppm}$.

In the present investigation in water in the Glebokie lake, it was observed that the maximum concentration of $\mathrm{Cd}$ was $0.34 \mathrm{ppm}$ and the minimum was $0.19 \mathrm{ppm}$.

In the present investigation in water of the Lubiszewko lake, it was observed that the maximum concentration of $\mathrm{Cd}$ was $0.39 \mathrm{ppm}$ and the minimum was $0.19 \mathrm{ppm}$.

In the present investigation in water in the Przyleg lake, it was observed that the maximum concentration of $\mathrm{Cd}$ was 0.47 $\mathrm{ppm}$ and the minimum was $0.19 \mathrm{ppm}$.
The values obtained were found to be below the permissible limit of $2.0 \mathrm{ppm}$ set for inland surface water.

In the present investigation in water in the Barlineckie lake, it was observed that the maximum concentration of $\mathrm{Cr}$ was 0.97 ppm and the minimum was $0.23 \mathrm{ppm}$.

In the present investigation in water in the Glebokie lake, it was observed that the maximum concentration of $\mathrm{Cr}$ was $0.42 \mathrm{ppm}$ and the minimum was $0.12 \mathrm{ppm}$.

In the present investigation in water in the Lubiszewko lake, it was observed that the maximum concentration of $\mathrm{Cr}$ was $0.24 \mathrm{ppm}$ and the minimum was $0.13 \mathrm{ppm}$.

In the present investigation in water in the Przyleg lake, it was observed that the maximum concentration of $\mathrm{Cr}$ was 0.27 ppm and the minimum was $0.13 \mathrm{ppm}$.

Which was very much above the permissible limit of 0.1 ppm set for inland surface water.

From the results it appears that the $\mathrm{Cu}$ content in water in the Barlineckie lake was minimum of $0.04 \mathrm{ppm}$ and maximum of $0.08 \mathrm{ppm}$.

From the results it appears that the $\mathrm{Cu}$ content in water in the Glebokie lake was minimum of $0.03 \mathrm{ppm}$ and maximum of $0.08 \mathrm{ppm}$

From the results it appears that the $\mathrm{Cu}$ content in water in the Lubiszewko lake was minimum of $0.03 \mathrm{ppm}$ and maximum of $0.08 \mathrm{ppm}$.

From the results it appears that the $\mathrm{Cu}$ content in water in the Przyleg lake was minimum of $0.03 \mathrm{ppm}$ and maximum of 0.09 ppm.

Which was below the permissible limit of $3.0 \mathrm{ppm}$ set for inland surface water.

In the present investigation in water in the Barlineckie lake, it was observed that the maximum concentration of $\mathrm{Hg}$ was $0.07 \mathrm{ppm}$ and the minimum was $0.02 \mathrm{ppm}$

In the present investigation in water in the Glebokie lake, it was observed that the maximum concentration of $\mathrm{Hg}$ was $0.07 \mathrm{ppm}$ and the minimum was $0.03 \mathrm{ppm}$.

In the present investigation in water in the Lubiszewko lake, it was observed that the maximum concentration of $\mathrm{Hg}$ was $0.08 \mathrm{ppm}$ and the minimum was $0.03 \mathrm{ppm}$

In the present investigation in water in the Przyleg lake, it was observed that the maximum concentration of $\mathrm{Hg}$ was 0.08 ppm and the minimum was $0.03 \mathrm{ppm}$.

Which was very much above the maximum limit of 0.01 ppm set for inland surface water.

The monthly concentration of $\mathrm{Ni}$ in the water in Barlinek lake samples was found to be in the range of 1.73-2.92 ppm. The monthly concentration of $\mathrm{Ni}$ in the water in Glebokie lake samples was found to be in the range of 1.21-2.38 ppm.

The monthly concentration of $\mathrm{Ni}$ in the water in Lubiszewko lake samples was found to be in the range of 1.40$2.62 \mathrm{ppm}$.

The monthly concentration of $\mathrm{Ni}$ in the water in Przyleg lake samples was found to be in the range of 1.41-2.74 ppm.

In the present investigation in water in the Barlineckie lake, it was observed that the maximum concentration of $\mathrm{Pb}$ was $0.09 \mathrm{ppm}$ and the minimum was $0.04 \mathrm{ppm}$.

In the present investigation in water in the Glebokie lake, it was observed that the maximum concentration of $\mathrm{Pb}$ was $0.07 \mathrm{ppm}$ and the minimum was $0.03 \mathrm{ppm}$. 
In the present investigation in water in the Lubiszewko lake, it was observed that the maximum concentration of $\mathrm{Pb}$ was $0.07 \mathrm{ppm}$ and the minimum was $0.03 \mathrm{ppm}$.

In the present investigation in water in the Przyleg lake, it was observed that the maximum concentration of $\mathrm{Pb}$ was 0.08 ppm and the minimum was $0.03 \mathrm{ppm}$.

In the present study in water in the Barlineckie lake, the monthly concentration of zinc was in the range of $2.27 \mathrm{ppm}$ to $3.70 \mathrm{ppm}$. In the present study in water in the Glebokie lake, the monthly concentration of zinc was in the range of $1.40 \mathrm{ppm}$ to $3.78 \mathrm{ppm}$. In the present study in water in the Lubiszewko lake, the monthly concentration of zinc was in the range of $1.79 \mathrm{ppm}$ to $3.63 \mathrm{ppm}$. In the present study in water in the Przyleg lake, the monthly concentration of zinc was in the range of $1.69 \mathrm{ppm}$ to $3.76 \mathrm{ppm}$.

\section{REFERENCES}

1. N.A. Ali, M. Ater, G.L. Sunahara and P.Y. Robidoux, Ecotoxicol. Environ. Safety, 57, 363 (2004)

2. AMAP, Assessment Report: Arctic Pollution Issues, Arctic Monitoring and Assessment Programme, Oslo (1998)

3. D.B. Lovejoy, Acta Zool. Lituanica, 9, 12 (1999).

4. H. Bradl, Heavy Metals in the Environment: Origin, Interaction and Remediation, Elsevier/Academic Press, London (2005).

5. L. Cai, G. Liu, C. Rensing and G. Wang, BMC Microbiol., 9, 4 (2009).

6. P. Daniszewski, Int. Lett. Chem., Phys. Astron., 4, 112 (2012).

7. L. Ember, Environ. Sci. Technol., 13, 769 (1979).

8. S.K. Jha, S.B. Chavan, G.G. Pandit, B.S. Negi and S. Sadasivan, Environ. Monit. Assess., 76, 249 (2002).

9. W.J. Adams, R.A. Kimerle and J.W. Barnett Jr., Environ. Sci. Technol., 26, 1864 (1992).

10. A. Aghor, Chemicals Make Thane Creek the Worst Polluted Waterbody, Daily DNA, August 4, 2007. Mumbai, India (2007).

11. D.H. Baldwin, J.F. Sandahl, J.S. Labenia and N.L. Scholz, Environ. Toxicol. Chem., 22, 2266 (2003).

12. I.K. Konstantinou, D.G. Hela and T.A. Albanis, Environ. Pollut., 141, 555 (2006)

13. R. Dallinger, F. Prosi, H. Segner and H. Back, Oecologia, 73, 91 (1987).

14. P. Daniszewski, Int. Lett. Chem., Phys. Astron., 3, 86 (2012).

15. P. Daniszewski and R. Konieczny, Int. Lett. Chem., Phys. Astron., 8, 269 (2013).

16. P. Daniszewski and R. Konieczny, Int. Lett. Chem., Phys. Astron., 8, 279 (2013).

17. C.D. Ezeonyejiaku, M.O. Obiakor and C.O. Ezenwelu, Online J. Anim. Feed Res., 1, 130 (2011).

18. J.S. Alabaster and R. Lloyds, Water Quality Criteria for Freshwater Fish, Butterworths Publication, London, edn. 2, p. 361 (1982).

19. P.U. Singare, K.U. Naik and R.S. Lokhande, Interdiscipl. Environ. Rev., 12, 215 (2011).

20. P.U. Singare, R.S. Lokhande and S.V. Bhanage, Int. J. Global Environ. Issues, 11, 79 (2011)

21. Y.D. Guan, G.X. La, J. Cao, Y.H. Du, Z.Y. Zhang, C. Ge and A.C. Luo, Asian J. Chem., 25, 4199 (2013).

22. N. Karakaya and F. Evrendilek, Asian J. Chem., 25, 2622 (2013).

23. P.U. Singare, R.M. Mishra and M.P. Trivedi, Adv. Anal. Chem., 2, 14 (2012).

24. P.U. Singare, R.M. Mishra and M.P. Trivedi, Frontiers Sci., 2, 28 (2012).

25. P.U. Singare, Thane Lakes High on Metal Content: Study, Daily Times of India, August 10, Mumbai, India (2011).

26. P.U. Singare, M.P. Trivedi and R.M. Mishra, Am. J. Chem., 2, 171 (2012).
27. P.U. Singare, M.P. Trivedi and R.M. Mishra, Sci. Technol., 2, 87 (2012).

28. P.U. Singare, M.S. Talpade, D.S. Dagli and V.G. Bhawe, Int. Lett. Chem., Phys. Astron., 8, 94 (2013).

29. C. Cervantes, J. Campos-García, S. Devars, F. Gutiérrez-Corona, H. Loza-Tavera, J.C. Torres-Guzmán and R. Moreno-Sánchez, FEMS Microbiol. Rev., 25, 335 (2001).

30. M. Chen and L.Q. Ma, Soil Sci. Soc. Am. J., 65, 491 (2001).

31. L.S. Clesceri, in eds.: E. Arnold, Greenbergy and A.D. Eaton, Standard Methods for the Examination of Water and Wastewater, In: Collection and Preservation of Samples And Metals, pp. 1-27, pp. 1-35, pp. 3-1, pp. 3-21, APHA, AWWA, WEF, Washington DC (1998).

32. P. Daniszewski, Int. Lett. Chem. Phys. Astron., 5, 80 (2012).

33. B.K. Dube, K. Tewari, J. Chatterjee and C. Chaterejee, Chemosphere, 53, 1147 (2003).

34. B.C. Gbaruko, G.R.E.E. Ana and J.K. Nwachukwu, African J. Biotechnol., 7, 4737 (2008).

35. Health Organization, International Programme on Chemical Safety (IPCS), Geneva, Switzerland (1992).

36. R. Hess and B. Schmid, J. Paediatr. Haematol./Oncol., 24, 582 (2002).

37. M.T. Horne and W.A. Dunson, Arch. Environ. Contamin. Toxicol., 29, 500 (1995).

38. A. Kabata-Pendias and H. Pendias, Trace Elements in Soils and Plants, CRC Press, Boca Raton, edn. 2, p. 365 (1992).

39. T.G. Kazi, M.B. Arain, J.A. Baig, M.K. Jamali, H.I. Afridi, N. Jalbani, R.A. Sarfraz, A.Q. Shah and A. Niaz, Sci. Total Environ., 407, 1019 (2009).

40. H.A. Kehrig, O. Malm and I. Moreira, Sci. Total Environ., 213, 263 (1998).

41. R.P. Khunyakari, T. Vrushali, R.N. Sharma and V. Tare, J. Environ. Biol., 22, 141 (2001).

42. R.S. Lokhande and N. Kelkar, Indian J. Environ. Prot., 19, 664 (1999).

43. R.S. Lokhande, P.U. Singare and D.S. Pimple, Resour. Environ., 1, 13 (2011).

44. R.S. Lokhande, P.U. Singare and D.S. Pimple, World Environ., 1, 6 (2011).

45. W. Maher, G.E. Batley and I. Lawrence, Freshwater Biol., 41, 361 (1999).

46. N. Menounou and B.J. Presley, Arch. Environ. Contam. Toxicol., 45, 11 (2003).

47. J.W. Moore and S. Ramamoorthy, Heavy Metals in Natural Waters: Applied Monitoring and Impact Assessment, Springer-Verlag, New York, pp. 28-246 (1984).

48. J.M. Neff, Environ. Toxicol. Chem., 16, 917 (1997).

49. A. Paar, Microwave Sample Preparation System-Instruction Handbook, Anton Paar GmbH, Austria, p. 128 (1998).

50. D. Patil, A Lot's Fishy About Our Creek and Lake Fish, Daily Times of India, March 22, Mumbai, India (2009).

51. A.J. Pyatt, F.B. Pyatt and V.W. Pentreath, Invertebr. Neurosci., 4, 135 (2002).

52. U.N. Rai, R.D. Tripathi and N. Kumar, Chromosphere, 25, 1721 (1992).

53. K.S. Rozsa and J. Salanki, Cell Mol. Neurobiol., 14, 735 (1994).

54. S.M. Ruby, R. Hull and P. Anderson, Arch. Environ. Contam. Toxicol., 38, 46 (2000).

55. J. Janczak, Atlas Polish Lakes, pp. 98-99 (1996).

56. S.L. Sachdev and P.W. West, Environ. Sci. Technol., 4, 768 (1970).

57. R.K. Sharma, M. Agrawal and F.M. Marshall, Effects of Wastewater Irrigation on Heavy Metal Accumulation in Soil and Plants, Paper Presented at the National Seminar, Bangalore University, Bangalore, India (2004).

58. N.S. Tiwana, N. Jerath, G. Singh and Ravleen, Heavy Metal Pollution in Punjab Rivers, in Newsletter Environmental Information System (ENVIS), Punjab State Council for Science and Technology, India, 3(1) (2005).

59. B. Taub Frieda, Fish 430 lectures (Biological Impacts of Pollutants on Aquatic Organisms), University of Washington College of Ocean and Fishery Sciences, Seattle, WA (2004). 